\title{
Why the long finger? Observation of male-male combat in African bush squeaker frogs, Arthroleptis stenodactylus (Anura: Arthroleptidae)
}

\author{
GABRIELA B. BITTENCOURT-SILVA ${ }^{1 *}$, DAVID LANGERMAN ${ }^{2}$ \& KRYSTAL A. TOLLEY 3,4 \\ ${ }^{1}$ Natural History Museum, Cromwell Road, SW7 5BD, London, UK \\ ${ }^{2}$ Dave Langerman Safaris \\ ${ }^{3}$ South African National Biodiversity Institute, Kirstenbosch Research Centre, Private Bag X7, Claremont, 7735, South Africa \\ ${ }^{4}$ Centre for Ecological Genomics and Wildlife Conservation, University of Johannesburg, Auckland Park, Johannesburg South Africa \\ *Corresponding author e-mail: g.bittencourt@nhm.ac.uk
}

Sasis exual dimorphism has been widely reported among anurans. In general, male frogs use advertisement calls to attract females and to defend territory (Duellman \& Trueb, 1986). Male secondary sexual traits, such as spines, tusks and nuptial excrescences, are not uncommon in anurans and are associated with defensive behaviours and, in the case of nuptial excrescences, may increase grip during amplexus - they are best developed in stream breeders (Duellman \& Trueb, 1986). Another form of secondary sexual trait is observed in males of the arthroleptid genera Arthroleptis and Cardioglossa. In most species of these genera, widely distributed across subSaharan Africa, sexually mature males present elongate third fingers and spines on the median surface of fingers (second and third) and groin (inguinal) region (Blackburn, 2009). In some cases the length of the male third finger can reach up to 30-40 \% snout-vent length (SVL) (Blackburn, 2009), and in Arthroleptis stenodactylus Pfeffer, 1893 the third finger length varies with SVL (Schmidt \& Inger, 1959). The function of this trait is unclear and the only account suggests that it can be related to combat behaviour. Amiet (1989) reported a malemale combat of $A$. poecilonotus Peters, 1863 from Cameroon: "...these frogs were standing on their hind limbs, with the fore limbs under the arms of the other, and with their elongate third finger vibrating against each others' backs....." (as translated by Blackburn 2009, p.555).

In northern Mozambique, combat between two male $A$. stenodactylus (Fig. 1; YouTube, 2020) was observed at night after rain in November 2018, at a campsite on the outskirts of Nampula town ( $15^{\circ} 02^{\prime} 22^{\prime \prime} \mathrm{S}, 39^{\circ} 08^{\prime} 39^{\prime \prime} \mathrm{E} ; 390 \mathrm{~m}$ a.s.l.). Several males were heard calling at the same time as the two males were observed and filmed. Although three human observers were within $20-30 \mathrm{~cm}$ of the pair the entire time, they were not deterred by our presence, with their attention focussed solely on the fight. The behaviour reported here closely resembles the description of $A$. poecilonotus malemale combat (Amiet, 1989). From the time we first noticed the action the males engaged in combat twice - at first we thought it was a couple in amplexus. Only the second combat was filmed and lasted approximately 60 seconds. The two frogs were standing on their hind limbs, with fore limbs around each other, and their third finger can be observed vibrating against each other's back. The males seem to attempt to flip each other, disengaging and quickly reengaging, before the defeated male left. The winner started calling again soon after the combat.

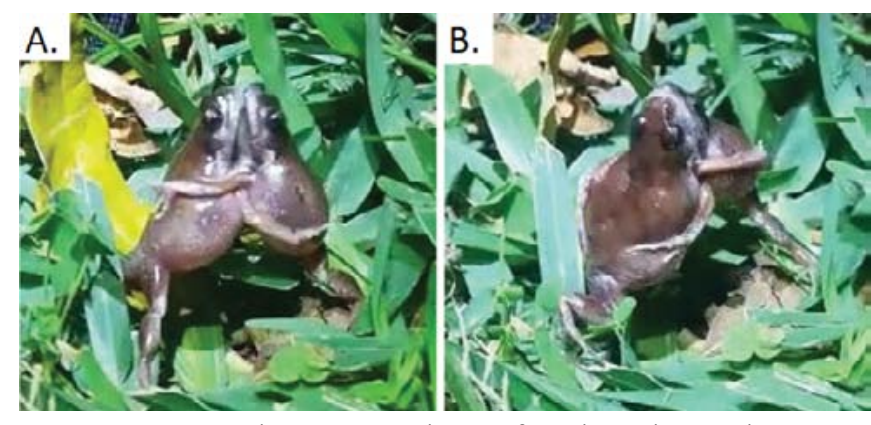

Figure 1. Two video screen shots of male-male combat in $A$. stenodactylus showing: A. The fight stance, and $\mathbf{B}$. Grasping with the elongated finger

To our knowledge, this is the second report and first footage of this behaviour in Arthroleptis. It reinforces the idea that this unusual sexual trait has evolved as a form of weapon. Although A. stenodactylus is commonly found East Africa, including anthropogenic environments, the observation of this behaviour has gone unreported until now. Natural history observations are fascinating and may help us understand the evolution and diversity of male sexual characters. We thank the National Geographic Society-Committee for Research and Exploration (9934-16) and the Percy Sladen Memorial Fund for funding this expedition.

\section{REFERENCES}

Amiet, J.L. (1989). Quelques aspects de la biologie des amphibiens anoures du Cameroun. Année Biologique. Paris 28: 73-116.

Blackburn, D.C. (2009). Diversity and evolution of male secondary sexual characters in African squeakers and longfingered frogs. Biological Journal of the Linnean Society 96(3): 553-573.

Duellman, W.E. \& Trueb, L. (1986). Biology of Amphibians. Baltimore: Johns $696 \mathrm{pp}$.

Schmidt, K.P. \& Inger, R.F. (1959). Amphibians exclusive of the genera Afrixalus and Hyperolius. In Exploration du Parc National de l'Upemba. Mission G.F. de Witte. Institut des Parcs Nationaux du Congo Belge, Bruxelles. Vol. 56, 1-264 pp YouTube (2020). Available at https://youtu.be/SG3JkEa8DW8 Accepted: 31 January 2020 